\title{
Announcing the Shape Memory and Superelasticity 2018 Editor's Choice Selections
}

(C) ASM International 2019

As editor, I am pleased to inform you that the following five papers have been selected as Editor's Choice. These five papers are now available as "Free Access" articles on Springer's website, which means the papers can be viewed 24/7 free worldwide at https://www.springer.com/materi als/characterization +\&+evaluation/journal/40830/PSE?de tailsPage $=$ press.

Cyclic Properties of Superelasticity in Cu-Al-Mn Single-Crystalline Sheets with Bainite Precipitates Ryosuke Kainuma, Yohei Yoshinaka, and Toshihiro Omori

Shap. Mem. Superelasticity, 2018, 4(4), p. 428-434

\section{H-Phase Precipitation and Martensitic}

Transformation in Ni-rich Ni-Ti-Hf and Ni-Ti-Zr High-Temperature Shape Memory Alloys

A. Evirgen, J. Pons, I. Karaman, R. Santamarta, and R. D. Noebe

Shap. Mem. Superelasticity, 2018, 4(1), p. 85-92

\section{Influence of Structure and Microstructure} on Deformation Localization and Crack Growth in NiTi Shape Memory Alloys

Partha P. Paul, Margaret Fortman, Harshad M. Paranjape, Peter M. Anderson, Aaron P. Stebner, and L. Catherine Brinson

Shap. Mem. Superelasticity, 2018, 4(2), p. 285-293

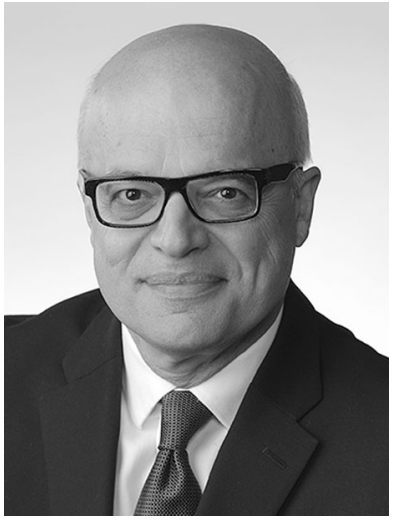

Diffusive Phenomena and the Austenite/Martensite Relative Stability in Cu-Based Shape-Memory

Alloys

J. L. Pelegrina, A. Yawny, and M. Sade

Shap. Mem. Superelasticity, 2018, 4(1), p. 48-60

\section{Frontiers of Theoretical Research on Shape} Memory Alloys: A General Overview

Piyas Chowdhury

Shap. Mem. Superelasticity, 2018, 4(1), p. 26-40

These selections are reflective of the comprehensive nature of the papers and their overall excellence. Only five papers are selected each calendar year as Editor's Choice articles from among all of the articles published in Shape Memory and Superelasticity and I congratulate the authors of the selected articles. The editorial team looks forward to this year's submissions to the journal.

Prof. Huseyin Sehitoglu

Editor-in-Chief

Shape Memory and Superelasticity 